\title{
EXPERIMENTS TO OBTAIN NEW BIOPRODUCTS BASED ON PROTEIN EXTRACTS FROM WET-WHITE LEATHER WASTE INTENDED FOR THE TOTAL OR PARTIAL REPLACEMENT OF PHENOL FORMALDEHYDE RESINS IN WET FINISHING OF LEATHER
}

\author{
Marian CRUDU ${ }^{1 *}$, Marian DEACONU², Melinda PRUNEANU ${ }^{3}$, Andra Manuela CONSTANTIN ${ }^{1}$, Dana GURĂU1 \\ ${ }^{1}$ INCDTP - Division: Leather and Footwear Research Institute, 93 Ion Minulescu, Bucharest
}

${ }^{2}$ ICECHIM Bucharest

3"Gh. Asachi" Technical University of Iasi

\section{EXPERIMENTS TO OBTAIN NEW BIOPRODUCTS BASED ON PROTEIN EXTRACTS FROM WET-WHITE LEATHER WASTE INTENDED FOR THE TOTAL OR PARTIAL REPLACEMENT OF PHENOL FORMALDEHYDE RESINS IN WET FINISHING OF LEATHER}

ABSTRACT. Leather retanning is a key operation in the wet finishing stage, playing a very important role in diversification of assortments, but at the same time using complex chemicals can induce important eco-toxic effects especially in the liquid effluents (residual float). This paper presents some of the achievements related to the expansion of eco-friendly auxiliary product range for wet finishing of leather (filling-retanning) with predominantly natural (protein) components, combined with metal oxides other than $\mathrm{Cr} 2 \mathrm{O} 3$ and without phenolic compounds, concomitantly with the leather industry's advance towards circular economy and increasing eco-efficiency. An experimental model was developed for functionalization of collagenic materials obtained by acid hydrolysis of pre-tanned wet-white bovine hide waste in order to obtain new bioproducts intended for the replacement of phenolic compounds for wet finishing of leather (filling-retanning). KEY WORDS: leather waste, circular economy, retanning products

EXPERIMENTĂRI DE OBTINERE DE NOI BIOPRODUSE PE BAZĂ DE EXTRACTE PROTEICE DIN DEŞEURI DE PIELE TĂBĂCITĂ ÎN SISTEM WETWHITE DESTINATE ÎNLOCUIRII TOTALE SAU PARTIALE A RĂŞINILOR FENOLFORMALDEHIDICE LA FINISAREA UMEDĂ A PIEILOR REZUMAT. Retăbăcirea pielii este o operaţie cheie în etapa de finisare umedă, jucând un rol foarte important în diversificarea sortimentelor, dar în acelaşi timp utilizarea substanţelor chimice complexe poate induce efecte eco-toxice semnificative, mai ales în efluenţii lichizi (flota reziduală). Această lucrare prezintă unele realizări legate de lărgirea gamei de produse auxiliare eco-prietenoase pentru finisarea umedă a pieilor (umplere-retanare) cu componente preponderent naturale (proteice) în combinaţie cu oxizi metalici alţii decât $\mathrm{Cr} 2 \mathrm{O} 3$ şi fără compuşi fenolici, concomitent cu apropierea industriei de pielărie de economia circulară şi creşterea eco-eficienţei. S-a dezvoltat un model experimental pentru funcţ̧ionalizarea materialelor colagenice obţinute prin hidroliză acidă a deşeurilor de piele bovină wet-white pretăbăcită pentru a obţine noi bioproduse destinate înlocuirii compuşilor fenolici la finisarea umedă a pielii (umplere-retanare).

CUVINTE CHEIE: deşeuri piele, economie circulară, produse retanare

\section{EXPÉRIENCES POUR OBTENIR DE NOUVEAUX BIOPRODUITS À PARTIR D’EXTRAITS PROTEIQUES DE DÉCHETS DE CUIR WET WHITE POUR LE REMPLACEMENT TOTAL OU PARTIEL DES RÉSINES PHÉNOL-FORMALDÉHYDE DANS LA FINITION DU CUIR}

RÉSUMÉ. Le retannage du cuir est une opération clé dans l'étape de finition humide, jouant un rôle très important dans la diversification des assortiments, mais en même temps, l'utilisation de produits chimiques complexes peut induire des effets écotoxiques importants, en particulier dans les effluents liquides (bain résiduel). Cet article présente quelques réalisations relatives à l'élargissement de la gamme de produits auxiliaires écologiques pour le finissage humide du cuir (remplissage-retannage) avec des composants principalement naturels (protéines), en combinaison avec des oxydes métalliques autres que $\mathrm{Cr} 2 \mathrm{O} 3$ et sans composés phénoliques, concomitamment avec le progrès de l'industrie du cuir vers l'économie circulaire et l'amélioration de l'efficacité écologique. Un modèle expérimental pour la fonctionnalisation de matériaux collagéniques obtenus par hydrolyse acide de déchets de cuir de bovins wet white a été développé afin d`obtenir de nouveaux bioproduits pour le remplacement des composés phénoliques dans l'étape de finition humide (remplissage-retannage). MOTS-CLÉS : déchets de cuir, économie circulaire, produits pour le retannage

\footnotetext{
* Correspondence to: Marian CRUDU, INCDTP - Division: Leather and Footwear Research Institute, 93 lon Minulescu, Bucharest, mariancrudu@yahoo.com
} 


\section{INTRODUCTION}

Leather tanned up to the wet-blue/wetwhite phase is processed according to typical technologies, diversification of assortments being carried out subsequently through wet finishing operations $[1,2]$.

If we study individually the factors that determine the diversification of assortments starting from the same type of substrate, we first find the existence of factors related to a series of constructive and functional characteristics of the machines used for wet and surface finishing.

Although the worldwide production of semi-finished leather is dependent both on the fluctuations of fashion (which from one season to another may evolve in the most unexpected directions) and on the ecological requirements of the consumers (for example, "free of chrome"/ FOC leather), the selected technologies must invariably take into account the favourable influences of each technological operation on:

- $\quad$ surface yield (economic aspect);

- improvement of the aesthetic characteristics, resistance, special characteristics etc. (qualitative aspect);

- environmental protection and safety of individuals, from tannery workers to users of leather products (ecological aspect).

Leather retanning is a key operation in the wet finishing stage, playing a very important role in diversification of assortments, but at the same time using complex chemicals can induce important eco-toxic effects especially in the liquid effluents (residual float).

Generally, for the correct management of the retanning operation, the properties and effects of auxiliary materials used must be taken into account, depending on the desired characteristics to be obtained for each assortment of semi-processed leather:
- the actual tanning effect;

- the filling effect;

- the influence of softness;

- the dispersion effect of natural tannins;

- $\quad$ the effect on the colour (dark/light);

- natural colour;

- the influence of the dyeing capacity;

- the influence of mechanical resistance;

- ecological implications.

This paper presents some of the achievements related to the expansion of ecofriendly auxiliary product range for wet finishing of leather (filling-retanning) with predominantly natural (protein) components, combined with metal oxides other than $\mathrm{Cr}_{2} \mathrm{O}_{3}$ and without phenolic compounds, concomitantly with the leather industry's advance towards circular economy and increasing eco-efficiency.

\section{MATERIALS AND METHODS}

\section{Materials}

The following materials were used in experiments:

- bovine leather tanned in wet-white system (INCDTP - Division ICPI), split and shaved;

- commercial auxiliary products for wet finishing of leather (neutralizing, fixing, acidifying, fatliquoring, washing, degreasing agents);

- pre-tanned bovine leather waste with titanium-zirconium based tanning agents (shavings) (INCDTP - Division ICPI);

- industrial water;

- acids for technical use (formic, lactic);

- commercial acrylic resin;

- aluminium triacetate (commercial product).

\section{Machines/Devices Used}

- CALORIS reactor (Romania) for hydrolysis of wet-white leather waste; 
- VALLERO rotating drum (Italy) for wet finishing of bovine leather;

- GIULLIANI device (Italy) for the determination of hydrothermal resistance (shrinkage temperature).

\section{Methods Used}

- laboratory analytical determinations for physical-chemical characterization of waste, collagen materials, new bioproducts, retanned leather in accordance with the regulations (standards) in force;

- physical-mechanical tests for the characterization of crust semi-finished leather obtained in accordance with the regulations in force.

\section{EXPERIMENTAL}

\section{Experimental Model for Obtaining Collagen Hydrolysates Extracted from Tanned Wet- white Leather Waste}

The use of protein materials (collagen) to obtain new auxiliaries for leather processing is an important component of research in the field [3-13]. Figure 1 schematically shows the experimental model for obtaining collagen hydrolysates from chrome-free tanned (wetwhite) leather waste.

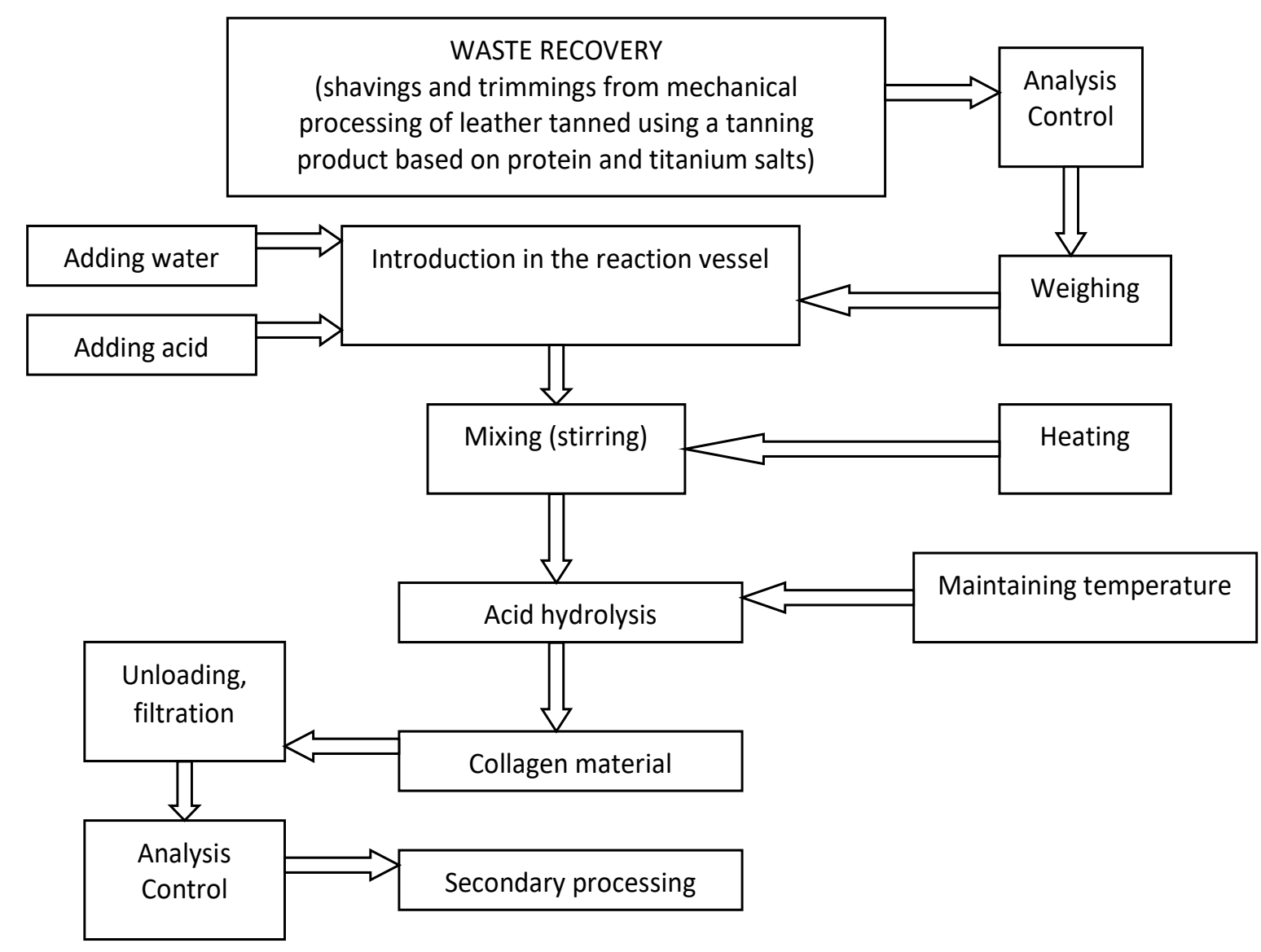

Figure 1. Diagram of the experimental model for obtaining collagen hydrolysates from chrome-free tanned (wet-white) leather waste 
Table 1 presents the technological algorithm (according to the proposed experimental model) for obtaining (hydrolysed)

Table 1: The technological algorithm for obtaining (hydrolysed) collagen for the formulation of new filling-retanning agents

\begin{tabular}{lccc}
\hline No. Operation & Method & Remarks \\
& & Formulation & Procedure \\
\hline
\end{tabular}

1. Waste recovery

2. Analysis/control

3. Grinding

4. Weighing

5. Filling the reaction vessel

6. Hydrolysis
30-35\% waste $60-70 \%$ water $2-5 \%$ formic acid

Shavings as well as trimmings are collected as a result of the shaving and trimming operation performed on wet-white leather pretanned with the HCT product (based on titanium oxides and proteins, both recovered from unrecyclable untanned hide waste)

Physical-chemical characterisation (see Table 4)

Only large pieces of trimming are ground

Waste is weighed to determine the net weight considered as reference for dosing the other materials

The reactor is filled in the specified order, under continuous stirring

$\begin{array}{ll}\text { Stirring is continued at the } & \text { Control } \\ \text { temperature of } 85-95^{\circ} \mathrm{C} \text { for } 12-24 \mathrm{~h} & \mathrm{pH}=4-5 \\ & \text { hydrolysate } \\ & \text { homogeneity }\end{array}$

Once released from the reactor, the obtained hydrolysate is filtered (Nuce filter, porous/textile material)

8. Analysis/control

Physical-chemical characteristics of the collagen material (hydrolysate containing metal oxides) are determined (see Table 2)

9. Weighing

The physical-chemical characteristics of the obtained collagen material (marked $R_{0}$ ) are presented in Table 2. 
Table 2: Physical-chemical characteristics of the collagen material obtained $\left(R_{0}\right)$

\begin{tabular}{clccl}
\hline No. & Characteristic & UM & Resulting values & \multicolumn{1}{c}{ Standard } \\
\hline 1. & Dry substance & $\%$ & $30-35$ & SR EN ISO 4684-2006 \\
2. & Ash & $\%$ & $25-30$ & SR EN ISO 4047-2002 \\
3. & Total nitrogen & $\%$ & $10.5-11.5$ & SR ISO 5397-96 \\
4. & Protein substance & $\%$ & $60-65$ & SR ISO 5397-96 \\
5. & pH 10\% solution & $\%$ & $4-5$ & STAS 8619/3-1990 \\
6. & Metal oxides & $\%$ & $20-22$ & \\
\hline
\end{tabular}

\section{Experimental Model of Formulation/ Functionalization of Protein Materials}

functionalization of protein materials in order to obtain new bioproducts for leather retanning.

Figure 2 schematically presents

the experimental model of formulation/

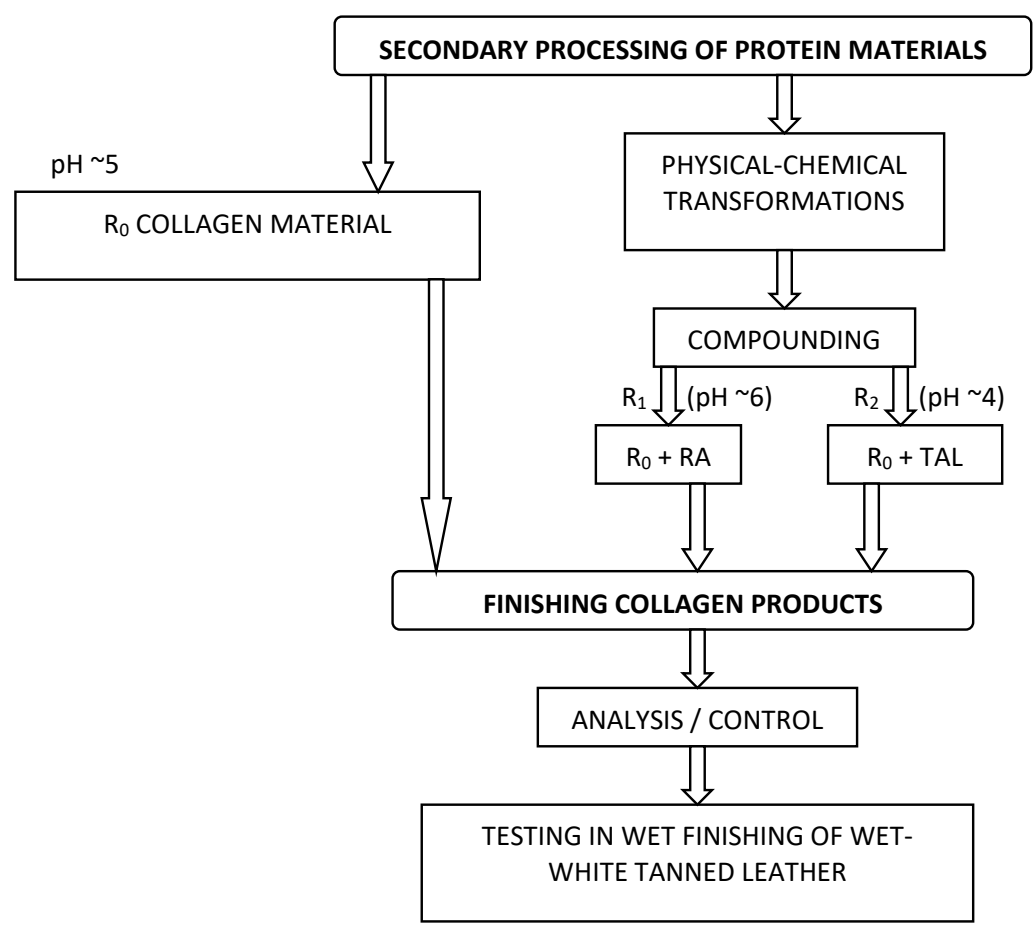

Figure 2. The experimental model of formulation/functionalization of protein materials in order to obtain new bioproducts for leather retanning $\left(R_{0}\right.$ : - collagen hydrolysate obtained by acid hydrolysis of leather waste tanned with titanium-zirconium-based products, $R_{1}: R_{0}+$ acrylic resin, $\mathrm{R}_{2}: \mathrm{R}_{0}$ + alumnium triacetate)

\section{Experimental Model for Obtaining New} Bioproducts for Leather Retanning

Table 3 presents the experimental model for obtaining new bioproducts for leather retanning. 
Table 3: Experimental model for obtaining new bioproducts for leather retanning

\begin{tabular}{|c|c|c|c|c|}
\hline \multirow[t]{2}{*}{ No. } & \multirow[t]{2}{*}{ Operation } & \multicolumn{2}{|r|}{ Method } & \multirow[t]{2}{*}{ Remarks } \\
\hline & & Formulation & Procedure & \\
\hline 1. & $\begin{array}{l}\text { Physical-chemical } \\
\text { transformation by } \\
\text { compounding }\end{array}$ & $\begin{array}{l}\text { R1 } 75-80 \% \text { R0 } \\
\text { 20-25 acrylic resin } \\
\text { R2 } 70-80 \% \text { R0 } \\
\text { 20-30 Al triacetate }\end{array}$ & $\begin{array}{l}\text { After adding acrylic resin and } \\
\text { the aluminium triacetate } \\
\text { compound, the mixture is } \\
\text { stirred for } 15-20^{\prime} \text { in a mixer- } \\
\text { type reaction vessel, the } \\
\text { compounding components } \\
\text { being solid and/or paste, } \\
\text { without exceeding the } \\
\text { temperature of } 30-35^{\circ} \mathrm{C}\end{array}$ & $\begin{array}{l}\text { Control: } \\
\text { Homogeneity of } \\
\text { resulting pastes is } \\
\text { controlled }\end{array}$ \\
\hline 2. & $\begin{array}{l}\text { Finishing collagen } \\
\text { products }\end{array}$ & & & \\
\hline 3. & Analysis/control & & $\begin{array}{l}\text { Physical-chemical } \\
\text { characteristics of the new } \\
\text { retanning bioproducts are } \\
\text { determined (see Table 4) }\end{array}$ & \\
\hline 4. & Unloading device & & & \\
\hline
\end{tabular}

Characterisation of New Bioproducts for Wet Finishing of Leather
Table 4 presents the physical-chemical characteristics of the new bioproducts intended for leather retanning.

Table 4: Physical-chemical characteristics of new bioproducts intended for leather retanning

\begin{tabular}{llcccl}
\hline No. & Characteristic & UM & \multicolumn{2}{c}{ Resulting values } & \multicolumn{1}{l}{ Standard } \\
& & & $\mathrm{R}_{1}$ & $\mathrm{R}_{2}$ & \\
\hline 1. & Dry substance & $\%$ & $33-36$ & $40-45$ & SRENISO 4684-2006 \\
2. & Ash & $\%$ & $25-30$ & $28-31$ & SRENISO 4047-2002 \\
3. & Total nitrogen & $\%$ & $9-10$ & $7.0-7.5$ & SRISO 5397-96 \\
4. & Protein substance & $\%$ & $50-55$ & $36-41$ & SRISO 5397-96 \\
5. & pH 10\% solution & $\%$ & $5.0-6.5$ & $4.0-4.5$ & STAS 8619/3-1990 \\
6. & Metal oxides & $\%$ & $9-11$ & $25-27$ & SRENISO 4684-2006 \\
\hline
\end{tabular}

Figure 3 shows the new biomaterials for wet finishing (retanning) of leather.

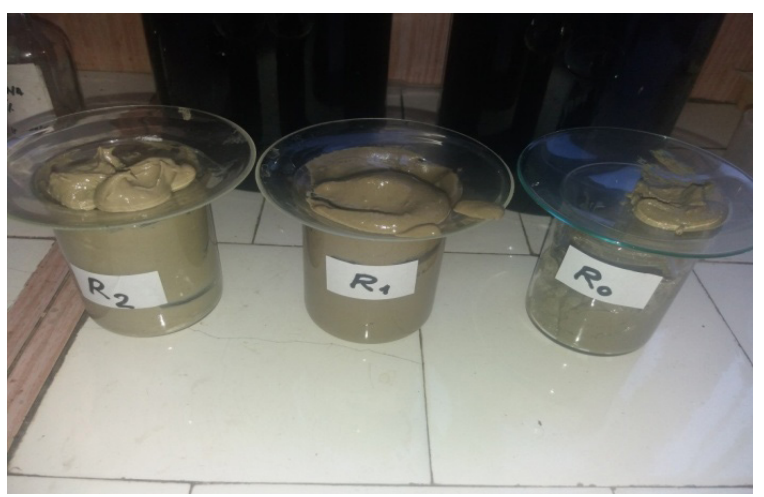

Figure 3. New biomaterials for wet finishing (retanning) of leather

\section{Testing New Bioproducts for Retanning Wet- white Bovine Leather}

Obtaining wet-white leather that will be used to test the new wet finishing materials

Table 5 presents the framework technology for obtaining wet-white leather. 
Table 5: The framework technology for obtaining wet-white leather

\begin{tabular}{|c|c|c|c|c|}
\hline \multirow[t]{2}{*}{ No. } & \multirow[t]{2}{*}{ Operation } & \multicolumn{2}{|c|}{ Method } & \multirow[t]{2}{*}{ Remarks } \\
\hline & & Formulation & Procedure & \\
\hline 1. & Pre/tanning & $\begin{array}{l}-30-70 \% \text { pickling float } 20-25^{\circ} \mathrm{C} \\
-3-5 \% \text { tanning agent based } \\
\text { on polyaldehyde and/or } \\
\text { glutaraldehyde } \\
-2-3 \% \text { pre-fatliquoring agent } \\
\text { resistant to electrolytes }\end{array}$ & $\begin{array}{l}\text { After adding the pre/tanning } \\
\text { agent the drum rotates for } \\
30^{\prime} \text { then the pre-fatliquoring } \\
\text { agent is added and stirring is } \\
\text { continued for another } 80-90^{\prime}\end{array}$ & $\begin{array}{l}\text { Control: } \\
\mathrm{pH}=2,8-2,9\end{array}$ \\
\hline 2. & Basification & $+0,5-1,5 \%$ self-basification agent & $\begin{array}{l}\text { After adding the self- } \\
\text { basification agent, the drum } \\
\text { rotates for 240-360' }\end{array}$ & $\begin{array}{l}\text { Control: } \\
\mathrm{pH}=3,9-4,2 \\
\mathrm{~T}_{\mathrm{s}}=70-75^{\circ} \mathrm{C}\end{array}$ \\
\hline 3. & Unloading drum & & & \\
\hline 4. & Rest & & $\begin{array}{l}\text { Leather left on the pallet for } 24- \\
48 \mathrm{~h}\end{array}$ & \\
\hline 5. & Sammying & $\begin{array}{l}\text { Sammying machine with cylinders } \\
\text { and felt }\end{array}$ & & \\
\hline 6. & Splitting & $\begin{array}{l}\text { Splitting machine with belt tape } \\
\text { knife }\end{array}$ & $\begin{array}{l}\text { Leather is split at a thickness as } \\
\text { close to that of shaving }(+0,1- \\
0,2 \mathrm{~mm})\end{array}$ & \\
\hline 7. & Shaving & Shaving machine with sharp knives & $\begin{array}{l}\text { Shaving at the required } \\
\text { thickness for the desired } \\
\text { assortment }\end{array}$ & \\
\hline 8. & Trimming & $\begin{array}{l}\text { Manually, using a knife/special } \\
\text { scissors }\end{array}$ & $\begin{array}{l}\text { Adhesions, areas with varying } \\
\text { thickness or unusable areas are } \\
\text { removed }\end{array}$ & \\
\hline 9. & Weighing & Calibrated industrial scales & $\begin{array}{l}\text { The net weight of shaved } \\
\text { leather is determined, as } \\
\text { reference for dosing floats and } \\
\text { wet finishing materials }\end{array}$ & \\
\hline
\end{tabular}

\section{Wet Finishing of Wet-white Bovine Leather Using the New Bioproducts}

Table 6 presents the technological algorithm for wet finishing of wet-white leather using the new bioproducts.

Table 6: Technological algorithm for wet finishing of wet-white leather using the new bioproducts

\begin{tabular}{|c|c|c|c|c|}
\hline \multirow[t]{2}{*}{ NO. } & \multirow[t]{2}{*}{ Operation } & \multicolumn{2}{|c|}{ Method } & \multirow[t]{2}{*}{ Remarks } \\
\hline & & Formulation & Procedure & \\
\hline 1. & Washing, degreasing & $\begin{array}{l}200 \% \text { float at } 30^{\circ} \mathrm{C} \\
0,5 \% \text { surfactant }\end{array}$ & Leather is drummed for $10-15^{\prime}$ & \\
\hline 2. & Draining & & & \\
\hline 3. & Neutralization & $\begin{array}{l}150 \% \text { float at } 30^{\circ} \mathrm{C} \\
2-3 \% \text { neutraliztion agent }\end{array}$ & $\begin{array}{l}\text { Leather is completely deacidified } \\
\text { in cross section. The drum rotates } \\
\text { for } 60^{\prime} \text {. If the section is not fully } \\
\text { neutralized, neutralisation is } \\
\text { continued until reaching the } \\
\text { desired effect (even over night with } \\
\text { intermittent stirring) }\end{array}$ & $\begin{array}{l}\text { Control: } \\
\text { pH=4,2-5,8 } \\
\varnothing=100 \% \text { VBC }\end{array}$ \\
\hline
\end{tabular}




\begin{tabular}{|c|c|c|c|c|}
\hline 4. & Draining & & & \\
\hline 5. & Washing & $200 \%$ float at $20-25^{\circ} \mathrm{C}$ & Leather is washed for 20-30' & \\
\hline 6. & Draining & & & \\
\hline 7. & Fatliquoring & $\begin{array}{l}100 \% \text { float at } 50-55^{\circ} \mathrm{C} \\
6-10 \% \text { oil mixture }\end{array}$ & Drum rotates for $40-60^{\prime}$ & $\begin{array}{l}\text { Organoleptic } \\
\text { control }\end{array}$ \\
\hline 8. & Fixing (acidification) & $+0,5 \%$ formic acid (diluted 1:10) & Leather is drummed for $15-20^{\prime}$ & $\begin{array}{l}\text { White base leather } \\
\text { (NR) }\end{array}$ \\
\hline 9. & Draining & & & \\
\hline 10. & Retanning & $\begin{array}{l}100 \% \text { float at } 30-35^{\circ} \mathrm{C} \\
3-8 \% \mathbf{R}_{0} / \mathbf{R}_{\mathbf{1}} / \mathbf{R}_{\mathbf{2}}\end{array}$ & & $\begin{array}{l}\text { Leather and float } \\
\text { control }\end{array}$ \\
\hline 11. & Fixing (acidification) & $+0,5 \%$ formic acid & Drum rotates for $15-20^{\prime}$ & $\mathrm{pH}=4-4,5$ \\
\hline 12. & Draining & & & \\
\hline 13. & Rinsing & $200 \%$ float at $20^{\circ} \mathrm{C}$ & & \\
\hline 14. & Unloading drum & & & \\
\hline 15. & Rest & Minimum $12 \mathrm{~h}$ & & \\
\hline
\end{tabular}

Figure 4 shows the crust leather obtained using the new materials (after drying and staking).

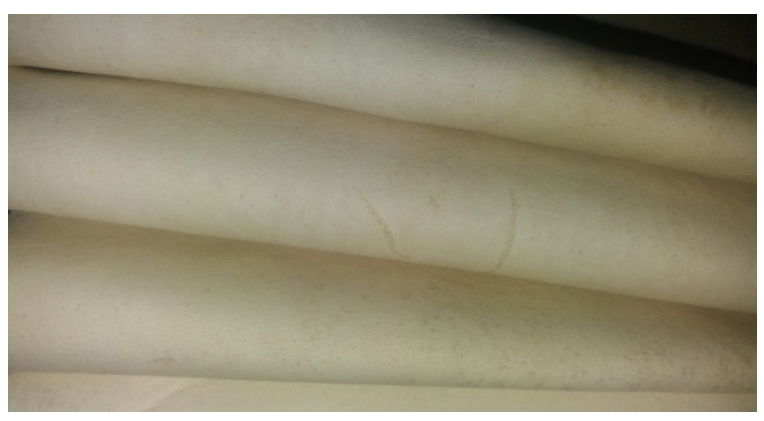

Figure 4. Crust leather obtained using the new materials (after drying and staking)

\section{RESULTS AND DISCUSSION}

The crust leather obtained using the new materials have organoleptic, physicalchemical and mechanical characteristics at least comparable to those of leather processed using classical technology.

\section{Characterization of Crust Wet-white Leather Using the New Bioproducts}

\section{Visual and Organoleptic Characterization}

Table 7 presents the visual-organoleptic characteristics of the crust leather wet finished using the new bioproducts.

Table 7: The visual-organoleptic characteristics of the crust leather wet finished using the new bioproducts

\begin{tabular}{|c|c|c|c|c|c|}
\hline No. & Characteristics & $\mathrm{Nr}$ & $\mathrm{R}_{0}$ & $\mathrm{R}_{1}$ & $\mathrm{R}_{2}$ \\
\hline 1. & Thickness (mm) & $0,8-0,9$ & $1,0-1,1$ & $1,1-1,2$ & $1,2-1,3$ \\
\hline 2. & Colour (visual) & $\begin{array}{l}\text { white-slightly } \\
\text { yellow }\end{array}$ & white-cream & white-cream & white-cream \\
\hline 3. & $\begin{array}{l}\text { Fullness } \\
\text { (organoleptic, marks 1-5) }\end{array}$ & 1 (poor) & 2-3 (moderate) & 4-5 (good, very good) & 5 (very good) \\
\hline 4. & $\begin{array}{l}\text { Softness } \\
\text { (organoleptic, marks 1-5) }\end{array}$ & 2-3 (moderate) & 3-4 (good) & 2-3 (moderate) & 5 (very good) \\
\hline 5. & $\begin{array}{l}\text { Grain appearance } \\
\text { (visual, organoleptic) }\end{array}$ & $\begin{array}{l}\text { smooth, slight } \\
\text { loosening }\end{array}$ & smooth, fine & smooth, full, firm & $\begin{array}{l}\text { smooth, full, } \\
\text { firm }\end{array}$ \\
\hline
\end{tabular}


Figure 5 shows the increase in thickness (volume) of the leather retanned with $\left(R_{0^{\prime}} R_{1}\right.$, $R_{2}$ ) compared to non-retanned leather (only fatliquored / white base).

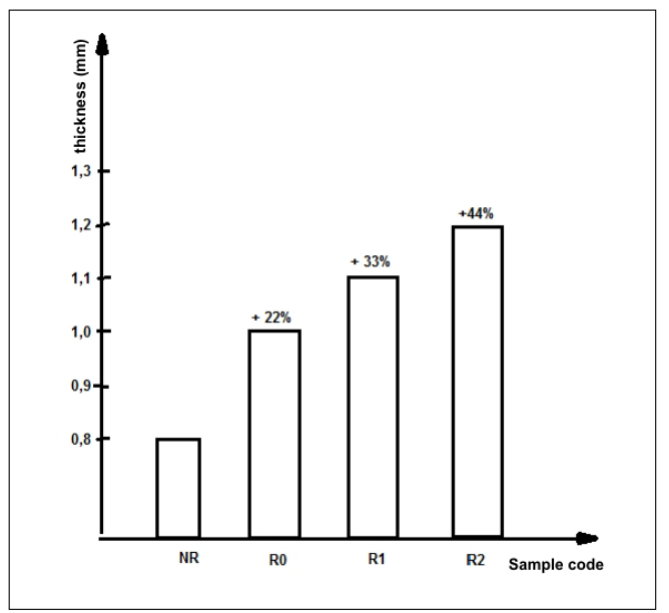

Figure 5. Thickness (volume) of the leather retanned with $\left(R_{0}, R_{1}, R_{2}\right)$ compared to nonretanned leather (only fatliquored / white base)
As seen from Table 7 and Figure 5, all the new bioproducts have very good filling ability, highlighted by the obvious increase in volume (thickness).

Characterization of crust (wet-white) leather retanned using the new bioproducts in terms of hydrothermal resistance

Table 8 shows the shrinkage temperature values of the crust leather retanned using the new bioproducts in terms of hydrothermal resistance.

Table 8: Shrinkage temperature values of crust leather retanned using the new bioproducts

\begin{tabular}{|c|c|c|c|c|c|c|c|c|}
\hline \multirow[t]{2}{*}{ No. } & \multirow[t]{2}{*}{ Characteristic } & \multirow[t]{2}{*}{ UM } & \multicolumn{5}{|c|}{ Sample code } & \multirow[t]{2}{*}{ Standard } \\
\hline & & & WW & NR & $\mathrm{R}_{0}$ & $\mathrm{R}_{1}$ & $\mathrm{R}_{2}$ & \\
\hline 1. & Shrinkage temperature & ${ }^{\circ} \mathrm{C}$ & $70-72$ & $75-76$ & $76-78$ & $78-80$ & $81-82$ & SR EN ISO 3380:2003 \\
\hline
\end{tabular}

Figure 6 shows an increase in hydrothermal resistance (shrinkage temperature) of the retanned leather (with $R_{0}, R_{1}, R_{2}$ ) compared to the non-retanned leather (only neutralized and fatliquored / white base) and the pre-tanned (wet-white) leather.

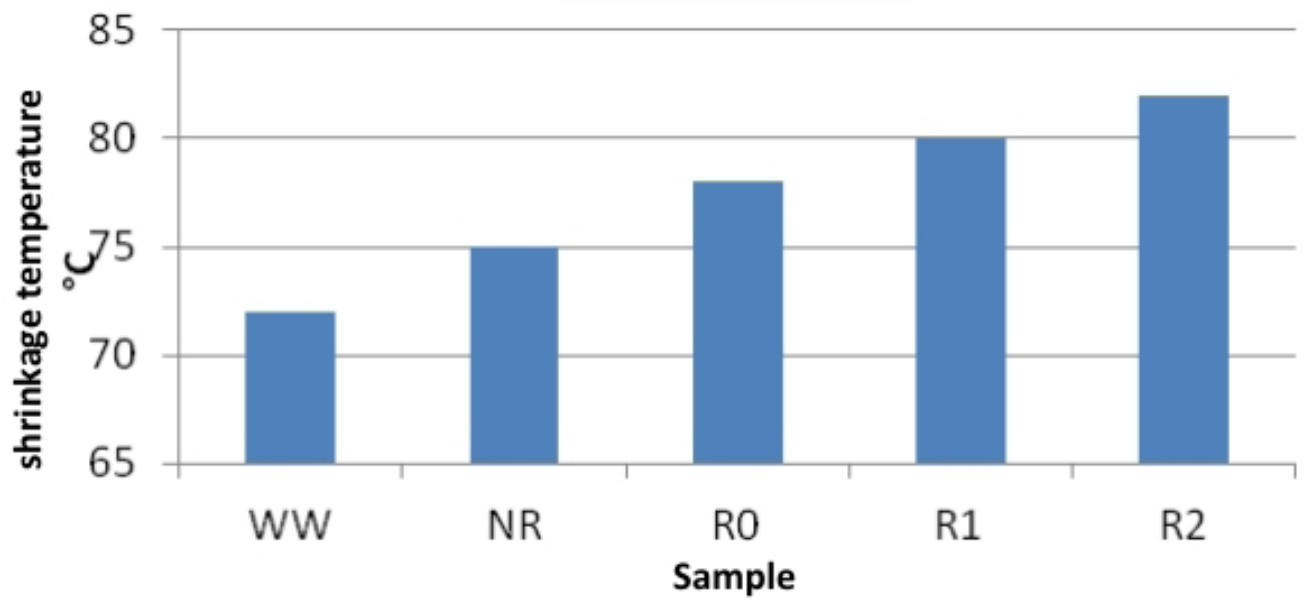

Figure 6. Shrinkage temperature of retanned leather (with $R_{0}, R_{1}, R_{2}$ ) compared to non-retanned leather (NR) (only neutralized and fatliquored / white base) and pre-tanned (wet-white) leather (WW) 
The new bioproducts for filling-retanning also have tanning ability, increasing hydrothermal resistance of leather (shrinkage temperature) by $4-12^{\circ} \mathrm{C}$.
Physical-chemical Characteristics of Crust (Wetwhite) Leather Wet Finished (Retanned) Using the New Bioproducts

Table 9 presents the physical-chemical characteristics of the crust (wet-white) leather wet finished (retanned) using the new bioproducts.

Table 9: Physical-chemical characteristics of crust (wet-white) leather wet finished (retanned) using the new bioproducts

\begin{tabular}{|c|c|c|c|c|c|c|c|c|c|c|c|}
\hline \multirow[t]{2}{*}{ No. } & \multirow[t]{2}{*}{ Characteristics } & \multirow[t]{2}{*}{ UM } & \multicolumn{8}{|c|}{ Sample code } & \multirow[t]{2}{*}{ Standard } \\
\hline & & & \multicolumn{2}{|c|}{ NR } & \multicolumn{2}{|c|}{$\mathrm{R}_{0}$} & \multicolumn{2}{|c|}{$\mathrm{R}_{1}$} & \multicolumn{2}{|c|}{$\mathrm{R}_{2}$} & \\
\hline \multirow[t]{5}{*}{1.} & $\begin{array}{l}\text { Tensile strength and } \\
\text { percent elongation }\end{array}$ & & & & & & & & & & $\begin{array}{l}\text { SR EN ISO } \\
3376-2012\end{array}$ \\
\hline & Elongation: & & & & & & & & & & \\
\hline & -at $10 \mathrm{~N} / \mathrm{mm}$ & $\%$ & 45 & 66 & 32 & 54 & 32 & 85 & 52 & 82 & \\
\hline & -at break & $\%$ & 75 & 104 & 68 & 54 & 74 & 128 & 91 & 120 & \\
\hline & -tensile strength & $\mathrm{N} / \mathrm{MM}$ & 9.6 & 20 & 10.3 & 10.0 & 27 & 17 & 21 & 16 & \\
\hline 2. & Tear strength & N/MM & 67 & 78 & 32 & 28 & 59 & 55 & 52 & 49 & \\
\hline
\end{tabular}

Physical-mechanical characteristics of crust leather obtained from wet white retanned with the new bioproducts are comparable to those of similar assortments obtained internationally, and even with those of leather tanned using $\mathrm{Cr}$ salts and retanned with commercial products commonly used in the industry.

\section{Characterization of the Residual Float}

Table 10 shows the residual residual float in terms of phenol content when using the new retanning bioproducts $\left(R_{0}, R_{1}, R_{2}\right)$ compared to those used industrially (M).

Table 10: Characterization of residual float in terms of phenol content when using new retanning bioproducts $\left(R_{0}, R_{1}, R_{2}\right)$, compared with those used industrially $(M)$

\begin{tabular}{|c|c|c|c|c|c|c|c|}
\hline \multirow[t]{2}{*}{ No. } & \multirow[t]{2}{*}{ Characteristic } & \multirow[t]{2}{*}{ UM } & \multicolumn{4}{|c|}{ Sample code / resulting values } & \multirow[t]{2}{*}{ Standard } \\
\hline & & & M & $\mathrm{R}_{0}$ & $\mathrm{R}_{1}$ & $\mathrm{R}_{2}$ & \\
\hline 1. & Phenol content & $\mathrm{mg} / \mathrm{l}$ & $20-80$ & $0.4-0.5$ & $0.5-0.6$ & $0,5-0.7$ & SRISO 6439:2001 \\
\hline
\end{tabular}

\section{CONCLUSIONS}

An experimental model was developed for functionalization of collagenic materials obtained by acid hydrolysis of pre-tanned wetwhite bovine hide waste in order to obtain new bioproducts intended for the replacement of phenolic compounds for wet finishing of leather (filling-retanning).

The use of new bioproducts in the wet finishing of bovine leather (retanning-filling) has led to:
- semi-processed wet-white crust bovine leather with physical-mechanical and aesthetic characteristics at least comparable to those produced internationally but also to those produced industrially with classical recipes (tanned with chrome salts and using phenolic compounds for retanning-filling);

- non-modification of existing industrial technologies; 
- anobvious retanning effectcharacterized by an increase in shrinkage temperature by $8-12^{\circ} \mathrm{C}$, a $10-30 \%$ increase in volume, which gives leather fullness and superior strength.

In addition to technical advantages presented above, production and use of new bioproducts based on collagen hydrolysate extracted from waste resulting from leather processing intended to replace the materials currently used for filling-retanning of leather (phenolic compounds) also induce multiple advantages, such as:

- environmental:

- reduction/elimination of phenolic compounds from liquid effluents from wet finishing (from $20-80 \mathrm{mg} / \mathrm{l}$ to 0.5 $0.7 \mathrm{mg} / \mathrm{l}$ phenol);

- social:

- protection of tannery workers by eliminating some compounds with ecotoxic potential (phenolic compounds);

- the possibility of creating new jobs through the creation of chemization stations in the tanneries;

- economic:

- the reduction of depollution, storage and/or waste elimination expenses;

- obtaining high value products relatively simply;

- reduction of expenses for the purchase of auxiliary materials.

In conclusion, it can be stated that this work contributes to the expansion of the range of eco-friendly auxiliary products for wet finishing of leather (filling-retanning) with predominantly natural (protein) components concomitant with the leather industry's advance towards circular economy and increasing eco-efficiency.

\section{Acknowledgements}

This study was funded by the Minister of Research and Innovation through the Program
1 - Development of the National Research and Development System, Subprogram 1.2 - Institutional Performance - RDI excellence funding projects, Contract no. 6PFE/16.10.2018.

\section{REFERENCES}

1. Maier, S.S., Maier, V., Pruneanu, M., An oxirane-pendant-groups copolymer, active as syntan in leather processing, Scientific Study \& Research, 2006, VII (2), 453-461.

2. Popa, E., Balau Mandru, I., Pruneanu, M., Balau Mandru, T., Potential use of collagen hydrolysates from chamois leather waste as ingredient in leather finishing formulations, Annals of the University of Oradea, Fascicle of Textiles, Leatherwork, 2016, 17, 2, 203209.

3. Sundar, V.J., Gnanamani, A., Muralidharan, C., Chandrababu, N.K., Mandal, A.B., Recovery and utilization of proteinous wastes of leather making: a review, Rev Environ Sci Biotechnol, 2011, 10, 2, 151-163, https://doi. org/10.1007/s11157-010-9223-6.

4. Zague, V., A new view concerning the effects of collagen hydrolysate intake on skin properties, Arch Dermatol Res, 2008, 300, 9, 479-483, https://doi.org/10.1007/s00403008-0888-4.

5. Moskowitz, R.W., Role of collagen hydrolysate in bone joint disease, Semin Arthritis Rheum, 2000, 2, 87-99, https://doi.org/10.1053/ sarh.2000.9622.

6. Vasireddy, R., Paul, R., Mitra, A.K., Green Synthesis of Silver Nanoparticles and the Study Optical Properties, Nanomater Nanotechno, 2012, 2, 1-6, https://doi.org/10.5772/52329.

7. Sathish Kumar, V., Vijayaravind, S., Utilization of Tannery Shredded Waste as Fine Aggregate in Concrete, International Journal of Engineering Research and Technology, 2015, 4, 4, 484-486.

8. Zainescu, G., Albu, L., Deselnicu, D., 
Constantinescu, R.R., Vasilescu, A.M., A New Concept of Complex Valorization of Leather Wastes, Materiale Plastice, 2014, 51, 1, 9093.

9. Tang, K., Zheng, X., Li, W., Shelly, D.C., Casadonte, D.J., Modification of polyurethane finishing agent using collagen hydrolysate from chrome shavings, J Am Leather Chem As, 2010, 105, 2531.

10. Manzo, G., Fedele, G., Bufalo, G., Cuoio Pelli Materie Concianti, 1993, 69, 4, 173-178.

11. Maue, M.J., Agent for treatment for hide and pelts, USA Patent No. 4762522, 9.08.1988.
12. Mafia, G.J., Slomiana, M., Davis, J.F., Recent advances in collagen based technologies, J Am Leather Chem As, 2002, 97, 74-82.

13. ***, UNIDO, Fourteenth Session of the Leather and Leather Products Industry Panel, Zlin, Czech Republic, 1-58, 2000.

(C) 2019 by the author(s). Published by INCDTP-ICPI, Bucharest, RO. This is an open access article distributed under the terms and conditions of the Creative Commons Attribution license (http://creativecommons.org/licenses/ by/4.0/). 